\title{
EMPIRICAL STUdy OF CIVIL JUSTICE SYSTEMS: A LOOK AT THE LITERATURE
}

\author{
MICHAEL LINES*
}

The explottation of empirical methodologies has had a late start in law compared with other social sciences. Though there have been consistent calls for the scientific ssudy of lanv-related problem. since the late 1800s, the main impesus to actually begin conducting sophissicated and useful empirical studies has come from outside the profession, starting mainly in the 1950s. Since then, a growing number of evidence-based studies of legal ropics have appeared. some authored by those trained in the law', others by those trained in other disciplines, often as collaborative efforts, and occasionally by scholars trained in both the law and empirical methodology. Prominent subjects have been the behaviour of juries. procedural justice. case loads in specific court systems, judicial decision-making. the legal profession. the impact of law on society and irends in specific types of cases, especially medical malpractice and product liability suits. This fuorescence seems to have tailed off somewhat since the late 1980s. What follows is an informal, non-exhanstive look at empirical studies relating to the reform of civil procedure and the improvement of the administration of civil jussice.
Dans le domaine du droit, l'exploitation des méthodologies heuristiques a commencé relativement tard comparativement $\dot{a} d$ autres sciences sociales. En fait. ca fait depuss la fin des annees 1800 que l'on exige une ėude scientifigue des problèmes rallachess à la loi, mais l'impulsion de commencer à mener des éludes heuristique's sophistiquées ef uniles $a$ int donnée dans les années 1950, et ce, à l'extérieur du domaine du droit. Depuis, un nombre grandissant d'études fondées sur les prewves de sujels juridiques ont vu le jour. Certaines effectuées par des personnes iravaillant dans le domaine juridique. d'autres par des personnes travaillant dans d'autres domaines. mais souvent le résultat provenais d'efforts collectifs. et à l'occasion. par des èrudits connaissant les domaines du droit et de la méthodologie heuristique. Parmi les sujets qui reviennent le plus souvent. ily a le comportement du jury. la justice en matière de procédure. le nombre de causes soumises aux tribunaux dans des ordres judiciaires précis, la prise de décisions judiciaires, la profession d'avocat. l'impact de la loi sur la société et les tendances de types de causes pricis, surtour la faute professionnelle médicale et les actions imtentes en responsabilité de produits. Cet intérit semble avoir diminud depuis la fin des annees 1980. Ce qui suit est un coup d'oul officieur et nullement limitatif sur des études heuristiques portant sur la réforme de la justice en matière de procidure at sur lamélioration de ladministration de la justice civile.

\section{TABLE OF CONTENTS}

1. INTRODUCTION ............................ 888

II. THE HISTORY OF THE EMPIRICAL STUDY OF PROCEDURE

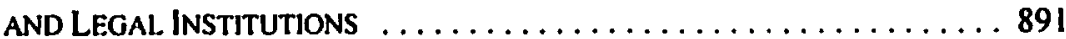

III. THE RESEARCHERS AND THEIR JOURNALS $\ldots \ldots \ldots \ldots \ldots \ldots \ldots \ldots .894$

A. Traditional Legal Researchers $\ldots \ldots \ldots \ldots \ldots \ldots \ldots .694$

B. Social Scientists ....................... 896

C. INTERDISCIPLINARY AND NON-TRADITIONAL

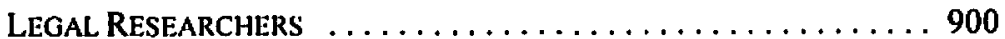

IV. RECENT DEVELOPMENTS $\ldots \ldots \ldots \ldots \ldots \ldots \ldots \ldots \ldots \ldots \ldots \ldots \ldots \ldots$

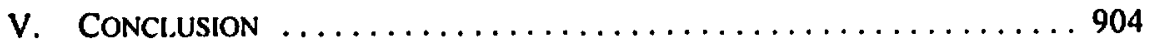

MA, MLS; Law Librarian and Information Coordinator, Canadian Forum on Civil Justice. The Forum mandate is to collect and share information and conduct research for the purpose of promoting reform of the civil justice system. The conclusions drawn here are my own. and do not necessarily reflect those of the Canadian Forum on Civil Justice (CFCJ). 


\section{INTRODUCTION}

Earlier this year, as part of my duties supporting the information needs of the Canadian Forum on Civil Justice, I was asked to find the full text of Roscoe Pound's famous address to the American Bar Association, "The Causes of Popular Dissatisfaction with the Administration of Justice." I located the speech and also ran across another work by Pound that caught my librarian's eye: "A Bibliography of Procedural Reform Including Organization of the Courts," published in 1917. ${ }^{2}$ When I looked at the titles that Pound had collected, I was struck by how familiar they seemed. The following is a selection from Pound that refers to the problem of delay in the courts:

- Report of the Special Committee to Prevent Delay and Unnecessary Costs in Litigation.

- Simplification of Judicial Procedure in Federal Courts.

- How Civil Procedure was Simplified in Connecticut.

- Law Schools and Reform in Procedure.

- Law's Delay.

- Efficiency in the Administration of Justice.

- The Struggle for the Simplification of Legal Procedure.

- Legal Efficiency.

- Delays and Reversals on Technical Grounds in Civil and Criminal Trials.

- Massachusetts Commission to Investigate the Causes of Delay in the Administration of Justice in Civil Actions: Report.

Preliminary Report on Efficiency in the Administration of Justice.

Committee to Consider the Simplification of New York Procedure: Report.

Report on a Plan for the Simplification of the Civil Practice of the Courts in that State [New York].

Experiment in Simplified Procedure.

Technicalities, So-Called.

On Ending the Scandal of the Law's Delays.

The Layman's Criticism of the Lawyer.

Simplification of Legal Procedure - Expediency must not Sacrifice Principle.

Administration of Justice - Its Speeding and Cheapening.

The Delays of the Law.

Today, of course, civil justice reform, including initiatives aimed at delay, remains a steady source of reports from government, bar associations and other law-related groups, as demonstrated in this selection from the recent Canadian professional and academic literature:
Excessive Costs and Delay: Is There a Solution?
Exploiting the Costs Symbiosis
L'accélération du temps juridique

1 Roscoe Pound, "The Causes of Popular Dissatisfaction with the Administration of Justice" (1936-1937) $20 \mathrm{~J}$. Am. Jud. Soc. 178. Originally delivered at the 1906 annual meeting of the American Bar
Association.

2

Roscoe Pound, "A Bibliography of Procedural Reform Including Organization of the Courts" (1917) 
- Preliminary Report Regarding Rule 66 Trials

- Slow Appeals: Causes and Cures

- Part 24 of the Alberta Rules of Court: Delay in Prosecution of Actions

- British Columbia Supreme Court Report of the Chief Judge: Delay and Backlog in the Provincial Court of British Columbia

- De la difficulté de rendre une justice rapide et peu coûteuse: une perspective historique, 1840-1965

- Projet sur la justice civile: l'utilisation de délais et les exigences relatives à la notification obligatoire dans la gestion des causes civiles

- Discovery Reform Subcommittee of the Civil Practice and Procedure Committee of the Court of Queen's Bench of Alberta: Final Report

- Caseflow Management: A Delay Reduction Tool

- The Ontario Law Reform Commission Report on Delay and Multiple Proceedings: A Critique

- Delay within the Administration of Justice in Proceedings Involving the Care, Custody and Access to Children

- Executive Summary: Inventory of Delay Reduction Strategies and Techniques

- National Time Standards for the Disposition of Civil Cases: A Discussion Paper

- Le délai de l'action directe en nullité.

The 1917 titles read like they could have been produced last year, and the modern titles could sit inconspicuously, for the most part, in Pound's collection. This has unfortunate implications for the administration of justice. Is delay really such an intractable problem that 100 years of reform suggestions has not found a workable solution?

Now, lest I be removed from the pulpit for judging books by their titles, a word on the content. Though I'm not an expert in procedure or court reform, when I began comparing works from the two lists it was obvious that while there were differences, there was nonetheless an arresting similarity as well: a pervasive scarcity of validly derived empirical data $^{4}$ and a corresponding lack of compelling evidence-based evaluations of the problem of delay.

For instance, this passage from a 1911 work published by Yale University Press makes its own kind of sense regarding the contributions that personal injury suits make to the question of delay (part of the author's argument is to eliminate certain classes of suit):

A person injured by an aceident and obliged to sue for damages, knows that on the extent and permanence of the injury depends the amount of the verdict, and hence until the case is ended is reasonably certain to

3 These materials were selected from results obtained by searching the Canadian Forum on Civil Justice's online database, the Civil Justice Clearinghouse, using the subject heading "Court Administration Congestion and Delay" accessed I Seplember 2004. See the Canadian Forum on Civil Justice, "Civil Justice Clearinghouse," online: Canadian Forum on Civil Justice <http://karl.srv.ualberta.ca/pls/ portal30/law.menu_search.show>, select "Clearinghouse". I have canvassed only a few subsections of the literature relevant to civil justice topics. This look at the literature emphasizes Canadian, American and British sources. I have not attempted to include Australian materials.

4 It is important to note that when I say "empirical," I do not only mean statistics. When dealing with a complex human institution, qualitative information has a very valuable role. In fact, it is now considered best to conduct empirical studies that collect both quantitative and qualitative data and I include both of these approaches in my use of the term "empirical." 
languish. During the whole interval between suit and trial, he is preparing his case, walching his symptoms, registering his uncomfortable feelings, and, in short, exactly reversing the process by which professors of Christian Science cure their patients... A man who wishes to get well will oflen do so, when one who does not may become a permanent invalid. If the trial results in defeat, this cvil consequence remains, unmitigated by damages... If, on the other hand, he recovers damages, the share which he gets seems affluence and is often spent recklessly... I remember once hearing the question raised in a large party of leading lawyers familiar with such cases, whether the recovery of damages in an accident suit benefitied the successful suitor, and with one accord they agreed that they had never known a case where the damages had really done anything but harm."

While some might find this theory attractive, it is important to note that in spite of using phrases such as "whole interval," "often spent recklessly," "large party of leading lawyers" and "had really done," there is no quantitative or qualitative evidence upon which the theory was based."

This practice is not uncommon today. I will not identify the many prominent contemporary jurists, lawyers and scholars who publish good advice for the improvement of the court system without a shred of data to back themselves up, lest I be further removed from the pulpit, or perhaps the parish. However I am not the first to admonish the legal community for this weakness: the tradition is long, and found often violent expression in Jeremy Bentham's work. He attributed the promotion of weak or useless reforms to the "sinister interests" of lawyers, and generally his opinion was that "[a]ll the industry of lawyers has been hitherto employed to prevent the grounds of law being canvassed." Pound was more moderate:

\footnotetext{
It has been fell for some time that the entire separation of jurisprudence from the other social sciences, the leaving of it to itself on the one hand and the conviction of its self-sufficiency on the other hand, was not merely unfortunate for the science of law on general considerations, in that it necessitated a narrow and partial view but was in large part to be charged with the backwardness of law in meeting social ends, the tardiness of lawyers in admitting or even perceiving such ends, and the gulf between legal thought and popular thought on matters of social reform. ${ }^{8}$
}

More recently, this comment was made: "the law and society movement will remain outside the law schools, pressing its nose against the glass... Should anybody care? Is enough going on in the university as a whole, among political scientists, sociologists, and others, so that we can ignore the backwardness of law schools?"' Finally, this zinger: "Many lawyers and judges appear to believe that thinking like a lawyer means relying on law books, logic, speculation, argument, and - when it comes to addressing problems of societal reality -

Moorfield Storey, The Reform of Legal Procedure (New Haven: Yale University Press, 191 1) at 52-53. Still, it is not true that in 1917 all works were entirely lacking in scientifically collected data. Mr. Storcy does include dollar amounts and numbers of trials as part of his argument (ibid. at 56), though his source is not fully cited. In facl. there was at that time a growing body of empirical studies taking shape in the U.S. for which see infra. Jeremy Bentham, Book of Fallacies in The Works of Jeremy, Bentham, ed. by John Bowring. vol. 2 (New York: Russell \& Russell, 1962) 375 at 479.

" Roscoe Pound, "The Scope and Purpose of Sociological Jurisprudence [part 3]" (1912) 25 Harv. L. Rev. 489 at 510 .

Lawrence M. Friedman, "The Law and Society Movement" (1986) 38 Stan. L. Rev. 763 at 778-79. 
invoking intuition ... [W]e are face-to-face with an old truth: [I]awyers are suspicious or fearful or both when they confront the methods and findings of the social sciences."10

Not that empirical studies are always required: there are situations where the facts are obvious and common sense is sufficient. And not that valid evidence is readily available, either: many categories of basic data that one assumes the courts generate in the regular course of business simply are not collected in Canada."

\section{The History of the Empirical Study of Procedure AND LEGAL INSTITUTIONS}

In Canada there seems to have been very few empirical studies published up to 1990. As an indication, one can look to Devlin's Canadian Perspectives on Legal Theory, ${ }^{12}$ which contains no mention of sociological approaches to law and no index entries for empirical studies.

Two excellent authoritative sources of information for the course of procedural reform over the past 200 years in Britain and the United States, are: Millar, ${ }^{13}$ who reviews the common law system to about 1950, and Van Caenegem, ${ }^{14}$ who surveys the whole history of the development of western procedure, including the nearly entire independent development of common law procedure up to about 1970.

The source, and for 50 years the only impetus, of the movement toward systematic reform of courts and procedure on rational lines was Jeremy Bentham. ${ }^{15}$ His Principles of Judicial Procedure $^{16}$ (published posthumously in 1843) led Henry Brougham and others to initiate the reforms of court structure and procedure that cumulated in the Judicature Acts of 1873

Maurice Rosenberg, "The Impact of Procedure-Impact Studies in the Administration of Justice" (1988) 51:3 Law \& Contemp. Probs. 13 at 13. For a more general taxonomy of anti-lawyer themes, see Marc Galanter, "Predators and Parasites: Lawyer-Bashing and Civil Justice" (1994) 28 Ga. L. Rev. 633. A shortcoming recognized, in the specific context of self-represented litigants, in D.A. Rollie Thompson, "No Lawyer: Institutional Coping with the Self-Represented" (2002) 19 Can. Fam. L.Q. 455. He then goes on to cite a number of revealing statistics he found elsewhere. This may change as the Canadian Centre for Justice Statistics moves to collect data on civil matters, see C. Brookbank, B. Kingsley \& T. Leonard, Civil Courrs Study Report (Ottawa: Canadian Centrc for Justice Statistics, 1999).

12 Richard F. Devlin, Canadian Perspectives on Legal Theory (Toronto: Emond Montgomery Publications, (991).

13 Robert Wyness Millar, Civil Procedure of the Trial Court in Historical Perspective (New York: Law Center of New York University, 1952); see also Robert W. Millar, "Procedure, Legal" in Edwin R. A. Seligman \& Alvin Johnson, eds., Encyclopaedia of the Social Sciences, vol. 12 (New York: Macmillan, 1934) 439 , for a more concise description with a useful bibliography.

R.C. Van Caenegem, "History of European Civil Procedure" in David René et al., eds. International Encyclopedia of Comparative Law, vol. 16 (New York: Oceana, 1996 [originally published 197I]) c. 2.

For a bricf review of some of the great British figures who acknowledge this, see Jack I.H. Jacob, "Civil Procedure since 1800" in The Reform of Civil Procedural Law and Other Essays in Civil Procedure (Agincourt, Ont.: Carswell. 1982) 193 at 207. See Henry Brougham. Speeches of Henry Lord Brougham. with Historical introductions, vol. 2 (Edinburgh: A. and C. Black. 1838) at 319 for the 1828 House of Commons speech that finally brought this issue into the open.

14. Jeremy Bentham. Principles of Judicial Procedure with the Ouline of a Procedural Code in The Works of Jeremy Bentham, ed. by John Bowring, vol. 2 (New York: Russell \& Russell, 1962 [originally published 1843]) 1 . 
and 1875. Benthamites cannot be credited alone, however. At the time there was a strong public interest and involvement in the subject of procedural reform, which, supported by an impressive media campaign, eventually defeated trenchant opposition to reform from within the judicial system and legal profession. ${ }^{17}$ The scientific spirit of the times played a decisive role in this transformation. As one writer in a popular publication put it: "We want, therefore, men of business, men of the world, and men accustomed to broad scientific researches, associated with lawyers in this work [of procedural reform]."18 Brougham in fact founded what was probably the first institute concerned with sociological research of legal issues, the National Association for the Promotion of Social Science, in 1857.'

It was only later in the 19th century, however, that scientific study of the legal system began to be conducted, and in the United States the main proponents of sociological or scientific investigation of the legal system in this period are generally considered to be of a Realist or proto-Realist stripe, including Oliver Wendell Holmes, David Dudley Field, ${ }^{20}$ Charles Clark and Roscoe Pound. The Realists tended to call for the profession to look to other disciplines to help resolve, in particular, the conflict between natural law and positivist positions in legal theory. Part of that effort can be seen in Pound's repeated calls for sociological studies of legal problems and legal institutions. ${ }^{21}$

The number of empirical studies of legal institutions increased until the political climate changed with the depression and WWII, but these studies had limited effect. They typically focused on counting cases or collecting similar data in a naive way, rather than on careful methodology and analysis. ${ }^{22}$ It seems no qualitative studies were conducted.

By the 1950 s, a more fully developed socio-legal theory and practice was available to American scholars in the work of three European sociologists: Eugen Ehrlich, ${ }^{23}$ Nicolas S. Timasheff $^{24}$ and Georges Gurvitch. ${ }^{25}$ Along with the appearance of the first English

Edson R. Sunderland, "The English Struggle for Procedural Reform" (1926) 39 Harv. L. Rev. 725. (1843) 38 Westminster Review 107-120, cited in ibid. at 739.

Jacob, supra note 15 at 208.

Field created the first revision of civil procedure in the United States in 1848: The New York Code of Procedure (1848). For background and the influences from and on England, see Millar, Civil Procedure of the Trial Court in Historical Perspective, supra note 13 at $52 \pi$.

See for instance Roscoe Pound, "The Scope and Purpose of Sociological Jurisprudence [part 1]" (1911) 24 Harv. L. Rev. 591; "The Scope and Purpose of Sociological Jurisprudence [part 2]" (1911) 25 Harv. L. Rev. 140; “The Scope and Purpose of Sociological Jurisprudence [part 3]," supra note 8. Also of note is his often-cited article "Law in Books and Law in Action" (1910) 44 Am. L. Rev. 12.

Paul D. Carrington, "Foreword: The Scientific Study of Legal Institutions" (1988) 51:3 Law \& Contemp. Probs. 1 at 2. In addition, their reform agendas sometimes influenced their results, see John Henry Schlegel, "American Legal Realism and Empirical Social Science: From the Yale Experience" (1979) 28 Buff. L. Rev. 459 and John Henry Schlegel, "American Legal Realism and Empirical Social Science: The Singular Case of Underhill Moore" (1980) 29 Bufr. L. Rev. 195.

Eugen Ehrlich, Fundamental Principles of the Sociology of Law, trans. by W.L. Moll (New Brunswick, N.J.: Transaction Publishers, 1962); Eugen Ehrlich, "The Sociology of Law" (1922) 36 Harv. L. Rev.
130.

Nicholas S. Timashefr, An Introduction to the Sociology of Law (New Brunswick, N.J.: Transaction Publishers, 2002) [originally published: Cambridge: Harvard University Committee on Research in the Social Sciences, 1939]. Georges Gurvitch, Sociology of Law, trans. by A. Hunt (New Brunswick, N.J.: Transaction Publishers,
1942). 
translation of Max Weber's work by Rheinstein in $1954,{ }^{26}$ this new socio-legal thinking began to have influence in the United States. Also, in the 1950s, Leon Petrazycki's psychosocial legal theory reached the United States in translation. ${ }^{27}$ By 1959 , there was sufficient interest in socio-legal investigation in the United States to justify an overview of the field, ${ }^{28}$ and in 1965 the corpus had grown enough to warrant a survey of the literature some 35 printed pages long. ${ }^{29}$

Some of the most prominent themes in the first 25 years following WWII can be briefly listed here. Much early work was done in criminal-related areas, ${ }^{30}$ but many studies had implications for both criminal and civil systems. The jury was the subject of one of the first truly sociological studies of law-related phenomenon, with the lead taken by the University of Chicago Jury Project. ${ }^{31}$ The legal profession itself was another major area of focus, ${ }^{12}$ and the rise of administrative law was also an object of study. ${ }^{33}$ A major area of concentration was the factors influencing judicial decision-making, ${ }^{34}$ and, in addition, the main ethical and methodological barriers to valid scientific studies of legal systems were identified. ${ }^{\text {js }}$ In specifically civil justice related areas the pretrial conference, ${ }^{36}$ access to justice, ${ }^{37}$ small

Max Weber, Max Weber on Law in Economy and Saciety, trans. by Edward Shils and Max Rheinstein (New York: Simon and Schuster, 1954).

Leon Petrazycki, Law and Morality, trans. by Hugh W. Babb (Cambridge: Harvard Universily Press, 1955).

Philip Selznick, "The Sociology of Law" in Robert K. Merton, Leonard Brown \& Leonard S. Cottrell Jr., eds., Sociology Today: Problems and Prospects (New York: Basic Books, 1959) 115.

Jerome H. Skolnick, "The Sociology of Law in America: Overview and Trends" (1965) Summer Social Problems 4. This overview was drawn from A. Javier Trevino, The Sociology of Law: A Bibliography of Theorefical Liferature, 3d ed. (Lewiston: Edwin Mellen Press, 2003) at 1 .

For instance Johan Thorsten Sellin \& American Law Institute, The Death Penalty: A Report for the Model Penal Code Project of the American Law Institute (Philadelphia: Executive Office, American Law Institute, 1959); Irving Piliavin \& Scott Briar, "Police Encounters with Juveniles" (1964) 70 American Journal of Sociology 206; and Robert O. Dawson, Sentencing: the Decision as to Type, Length, and Conditions of Sentence (Boston: Little, Brown, 1969). For a bibliography, see Leon Radzinowicz \& Roger Hood, Criminology and the Administration of Criminal Justice: A Bibliography (London: Mansell, 1976).

Harry Kalven \& Hans Zeisel, The American Jury (Boston: Little, 1966).

Jerome E. Carlin, Lanvyers on Their Own (New Brunswick. N.J.: Rutgers University Press, 1962).

Paul W. Tappan, Delinquent Girls in Court (New York: Columbia University Press, 1947).

Among several strains, we can single out one: the effect of worklond on the quality of U.S. Supreme Coun decisions. See e.g. Fowler V. Harper \& Alan S. Rosenthal, "What the Supreme Court Did Not Do in the 1949 Term - An Appraisal of Certiorari" (1950) 99 U. Pa. L. Rev. 293 and Henry M. Hart. Jr., "The Supreme Court 1958 Term, Forward: The Time Chart of the Justices" (1959) 73 Harv. L. Rev. 84.

The leading studies to define the limits of the debate on the ethics of experimentation in legal systems were Donald T. Campbell, "Reforms as Experiments" (1969) 24 American Psychologist 409; Richard Lempert, "Strategies of Research Design in the Legal Impact Study" (1966) I Law \& Soc'y Rev. 111: and later Federal Judicial Center, Advisory Committee on Experimentation in the Law, Experimentation in the Law: Report of the Federal Jindicial Center Advison. Commiltee on Experimentation in the Lan" (Washington, D.C.: The Center, 1981).

4. The first contsolled experiment in law was Maurice Rosenberg. The Preirial Conference and Effective Justice: A Controlled Test in Personal Injury Litigation (New York: Columbia University Press, 1964). See also Michael Stevenson, Garry D. Watson \& Edward Weissman, "The Impact of Pretrial Conferences: An Interim Report on the Ontario Pretrial Conference Experiment" (1977) 15 Osgoode Hall L.J. 591.

Mauro Cappelletti, Access to Justice (Milan: Sijthoff and Noordhoff, 1978). 
claims, ${ }^{38}$ litigation costs ${ }^{39}$ and procedure ${ }^{40}$ were prominent.

\section{THE RESEARChERS AND THEIR JOURNAlS}

In contrast to the pre-depression period, the most rigorous work in the 1950 s and $1960 \mathrm{~s}$ was carried out mainly by social scientists, with little help from legal academics. That began to change, and by 1965 the newly established Law and Society Association had prominent law professors on its Board. ${ }^{41}$ Since then, both social scientists outside law faculties and law professors with empirical research agendas have contributed substantially. In fact, the postwar study of law-related topics using social science methods appears to have developed in three main groups:

1. Those conducted within the legal mainstream by scholars trained in law and usually published in law journals;

2. Those conducted entirely outside legal academia and published in social science journals; and

3. Those produced within the profession, but outside of the mainstream, usually by or in conjunction with legal academics, and published in socio-legal and interdisciplinary journals, such as Law and Contemporary Problems, Law and Society Review, Journal of Legal Studies and the recently established Empirical Studies in Law. Interdisciplinary periodicals such as Journal of Law and Economics, Cornell Journal of Law and Public Policy and the Justice System Journal are also venues. ${ }^{42}$

\section{A. Traditional Legal Researchers}

Traditional, mainstream legal scholarship, still often referred to in its clerical aspect as "doctrinal," is textual in character, not empirical. In recent decades theoretical studies have increased in number and importance, but this has not produced a general intensification of interest in empirical work. There is nevertheless an awareness in law schools of the value of collecting new facts about the legal system, and certain systemic barriers to conducting empirical studies have been identified. ${ }^{43}$ In light of these historical realities, it may be something of a contradiction to try to identify empirical studies that are conducted by legal

Barbara Yngvesson \& Patricia Hennessey, "Small Claims, Complex Disputes: A Review of the Small Claims Literature" (1975) 9 Law \& Soc'y Rev. 219.

Alfred Fletcher Conard et al., Awomobile Accident Costs and Payments: Studies in the Economics of Reparation (Ann Arbor: University of Michigan Press, 1964).

Geoffrey C. Hazard, Research in Civil Procedure (New Haven: Walter E. Meyer Research Institute of Law, 1963).

Felice J. Levine, "Goose Bumps and 'The Search for Signs of Intelligent Life' in Sociolegal Studies: After Twenty-Five Years" (1990) 24 Law \& Soc'y Rev. 7 at 14.

These distinctions seem less important in the United Kingdom, where the university law schools and other rescarch groups seem to have absorbed non-lawyer researchers more readily. See John Baldwin \& Gwynn Davis, "Empirical Rescarch in Law" in Peter Cane \& Mark Tushnet, eds., The Oxford Handbook of Legal Studies (New York: Oxford University Press, 2003) 880 at 883. Still, British sociolegal scholars are anxious to define their field in distinction to mainstream, "doctrinal" legal research, see Philip A. Thomas, ed., Socio-Legal Srudies (Brookfield, Vt.: Dartmouth, 1997) at 4ff.

See Peter H. Schuck, "Why Don't Law Professors Do More Empirical Research?" (1989) 39 J. Legal Educ. 323 and Lee Epstein \& Gary King, "Building an Infrastructure for Empirical Research in the Law" (2003) $53 \mathrm{~J}$. Legal Educ. 311 
academics, if by that we mean those that are conducted within or close to the mainstream. This is true despite the fact that law schools have hired social scientists, in an effort to broaden their curricula. These professors, though they work and teach in law schools, still cannot be considered an integral part of legal education or legal scholarship:

To be sure [the social sciences] have a foot, or at least a toc, in the door of some law schools. Prestigious law schools offer courses in sociology, history or philosophy; or in psychology or anthropology of law. But everyone knows these are elegant frills, like thick rugs in the dean's office: they have nothing to do with "real" legal education."

Thus, there is a limited amount to say about the presence of empirical work in mainstream legal scholarship. Nevertheless, there are areas in which empirical studies are conducted, and which are receptive to empirical results conducted by others. Criminal law is foremost, but family, tort and areas of regulatory or "public" law are also major areas. Empirical approaches are employed more often, and to wider effect, in these areas for a number of reasons, perhaps the most interesting being the relatively small gap between academe and social policy: here, a researcher can hope to contribute to the policy debate. ${ }^{45}$

Another approach to mainstream legal scholarship is to consider the main subcategories of jurisprudence. Here also, empirical work has a very limited role. Most of the major schools of legal theory that are now prevalent were established in the 1960s, and while some cannot be considered mainstream in the above sense, all are by now influential in most law programs and are also well represented in the pages of mainstream legal journals. These approaches, such as Feminist and Marxist legal studies, Law and Economics and Critical Legal Studies, are heavily ideology driven, and for that reason are not particularly susceptible to the charms of empirical work. ${ }^{46}$

A couple of additional notes should be made on two areas of special relevance to mainstream treatments of civil justice issues: the teaching of procedure as described by Judith Resnick, and the reform of the civil justice system in Britain, as discussed by Jack I.H Jacob. While neither of these scholars has conducted empirical research, both have led mainstream legal academics to new views of civil justice issues that invite empirical approaches. In 1988, Resnick was co-author with Robert M. Cover and Owen M. Fiss of Procedure, a work that revamped the teaching of procedure to orient students toward the issues and problems that procedure addresses and generates. ${ }^{47}$ Jacob's The Fabric of English Civil Justice ${ }^{48}$ and The Reform of Civil Procedural Lav, ${ }^{49}$ though historical and rather "black letter" in approach, are landmarks that encourage systematic reforms of civil procedure.

Friedman, "The Law and Society Movement," supra note 9 at 777, quoted in S. Lloyd-Bostock. "Research and Teaching in Legal Psychology — an Outline of British Developments" (1994) 1 Psychology Crime \& Law 159 at 162.

4) Baldwin \& Davis, supra note 42 at 882,885 .

th Described as "lard, grubby rescarch" in Friedman, supra note 9 al 766. Occusionally cmpirical work does appear in these areas, such as in Richard Posner, The Federal Courts: Crisis and Reform (Cambridge, Mass.: Harvard University Press, 1985).

"William N. Eskridge, “Procedure: Robert M. Cover, Owen M. Fiss, Judith Resnik. New York: The Foundation Press, 1988," Book Review (1989) 98 Yale L.J. 945 at 949, n. 23. Jack 1.H. Jacob, The Fabric of English Civil Justice (London: Stevens, 1987). Supra note 15. 


\section{B. SOCIAL SCIENTISTS}

Rather than attempting to canvass in detail the whole range of empirical work on legal topics conducted by social scientists, here I will focus on a single strain of studies that can illustrate more clearly the depth of the materials that are available, and also their reception in the legal academy.

The study of procedural justice has been a topic of interest to social psychologists since the 1970 s. $^{50}$ It constitutes a good example of the range of work that can be done on a particular topic, from specific studies to theoretical statements based on them, and improvements in methodology arising from the experience of researchers. ${ }^{\text {sI }}$ The work is broad enough to have importance for most aspects of the justice system, but it is especially relevant to topics that bear on the conduct of trials.

The first major study in English, and the one that really opened up the field, was Thibaut and Walker's 1975 Procedural Sustice: A Psychological Analysis. ${ }^{52}$ Following this groundbreaking work, a series of other major studies appeared, including Greenberg and Folger (1983) detailing the fair process effect ${ }^{33}$ and Lind and Tyler (1988) on group value theory. ${ }^{54}$ In addition to these landmark works, there is a shelf of books published since the 1970 s on the topic ${ }^{55}$ and a large body of related articles. ${ }^{56}$

The field has precursors in the carly 1960 s, but developed mainly in response to two seminal works. The first, John Rawls, $A$ Theory of Justice (Cambridge, Mass.: Belknap Press of Harvard University Press, 1971) was a theoretical wosk attempting to define a universal, ideal procedure that would ensure a fair society. The second was Niklas Lulumann, Legitimation durch Verfahren ([Neuwied am Rhein]: Luchterhand, 1969) an empirical study showing the sometimes dark affects of procedural rules on the judicial process. The reply to Rawls in philosophy has been made by Jurgen Habermas, who attempts to replace Rawls' hierarchical, procedural model of justice seeking with '“'discourses' free of domination." See Jurgen Habermas, Justification and Applicallon: Remarks on Discourse Ethics (Cambridge, U.K.: Polity Press, 1993), cited in Klaus F. Rohl et al., Procedural Justice (Brookfield: Dartmouth, 1997) at xii.

"1 For a brief overview of the various kinds of law-oriented psychology, see Lloyd-Bostock, stupra note 44.

John W. Thibaut \& Laurens Walker, Procedural Justice: A Psychological Analysis (New York: L. Erlbaum Associates, 1975).

33 Jerald Greenberg \& Robert G. Folger, "Procedural Justice, Participalion, and the Fair Process Effect in Groups and Organizations" in Paul B. Paulus, ed., Basic Group Processes (New York: Springer-Verlag, 1983) 235.

44 E. Allan Lind \& Tom R. Tyler, The Social Psychology of Procedural Justice (New York: Plenum Press, 1988). This overview taken from Rohl ef al., supra note 50 at ix-xii. Interestingly, the cvolution of thought in these works, including Roht et al, ibid., fits with a developmental theory of law presented in Philippe Nonet \& Philip Selznick, Law and Society in Transition: Toward Responsive Law, ist ed. (New York: Harper \& Row, 1978), though Rohl et al. do not acknowledge it. Michael D. Bayles, Procedural Justice: Allocating to Individuals (Boston: Kluwer Academic Publishers, 1990); Jonathan D., Casper, Tom Tyler \& Bonnie Fisher, Procedural Jusfice in Felony Cases (Chicago: American Bar Foundation, 1988); George Meredith Cohen \& Susan P. Koniak, Foundations of the Law and Ethics of Lavyering (New York: Foundation Press, 2004); Russell Cropanzano, Justice in the Workplace: From Theory fo Practice (Mahwah, N.J.: L. Erlbaum Associates Publishers, 2001); Russell Cropanzano \& K. Michcle Kacmar, Organizational Politics, Justice and Support: Managing the Social Climate of the Workplace (Westpon, Conn.: Quorum, 1995); Monton Deutsch et al. Conflict, Cooperation and Justice: Essays Inspired by the Work of Morton Deutsch, 1 st ed. (San Francisco: Jossey-Bass Publishers, 1995); Robert Folger \& Russell Cropanzano, Organizational Justice and Human Resource Managemens (Thousand Oaks: Sage Publications, 1998); William A. Geller ef al, And Justice for All: Understanding and Controlling Police Abuse of Force 
The citation patterns ${ }^{37}$ generated by these three landmark works are revealing. Overall, these three have been cited 1857 times in all types of journals, including social science, business, management and law journals, among others. Just over twelve (12.7) percent of these citations appeared in "law" journals as classified by Web of Science, but that group includes non-traditional journals such as Law and Society Review and interdisciplinary journals such as Law and Behavioral Sciences. Only 6.5 percent of the citations appeared in what would be conventionally considered mainstream academic law journals, in spite of the fact that these works were partially addressed to the legal community (see Table 1 ). ${ }^{38}$

Table 1: Citations of Procedural Justice Books

\begin{tabular}{|l|c|c|c|}
\hline Work & $\begin{array}{c}\text { Number of } \\
\text { citations }\end{array}$ & $\begin{array}{c}\text { Citations in "law" } \\
\text { journals }\end{array}$ & $\begin{array}{c}\text { Citations in mainstream } \\
\text { law journals }\end{array}$ \\
\hline Thibaut \& Walker & 843 & $116(=13.8 \%)$ & $61(=7.2 \%)$ \\
\hline Greenberg \& Folger & 118 & $6(=5.1 \%)$ & $0(=0 \%)$ \\
\hline Lind \& Tyler & 896 & $115(=12.8 \%)$ & $61(=6.8 \%)$ \\
\hline Tolals & 1857 & $237(-12.7 \%)$ & $122(=6.5 \%)$ \\
\hline
\end{tabular}

It is also interesting to see the citation pattems for individual articles, since it is possible to reproduce more detailed results without taking up too much space. In particular, two

(Washington, D.C.: Police Executive Research Forum, 1995): II. Patrick Glenn \& Canada, Employment and Immigration Canada (Commission), Sirangers at the Gate: Refugees, Illegal Entrants and Procedural Justice (Cowansville, Qc.: İditions Y. Blais, 1992); Thomas F. Gordon. The Pleadings Game: An Artificial Intelligence Model of Procedural Justice (Boston: Kluwer Academic Publishers, 1995); Martin F. Kaplan, The Impact of Social Psychology on Procedural Justice (Springfield, IIl.: C.C. Thomas, 1986); Roderick M. Kramer \& Tom R. Tyler, Trust in Organizations: Frontiers of Theory and Research (Thousand Oaks: Sage Publications, 1996); Carol T. Kulik \& American Bar Foundation, Understanding Gender Differences in Distributive and Procedural Justice (Chicago: American Bar Foundation, 1993); Marion E. Lane \& Metropolitan Toronto (Ont.) Metropolitan Chairman's Special Committee on Child Abuse, The Legal Response to Sexual Abuse of Children: A Background Paper Reviewing Current Procedural and Legal Practices in the Child Welfare and Criminal Justice Systems Regarding Child Sexual Abuse (Toronto: Metropolitan Chairman's Special Committee on Child Abuse, 1982); E. Allan Lind \& American Bar Foundation. Procedural Justice, Disputing, and Reactions to Legal Authorities ([Chicago]: American Bar Foundation, 1994); David Luban, The Ethics of Lawyers (New York: New York University Press, 1994); John D. McCluskey. Police Requests for Compliance: Coercive and Procedurally Just Tactics (New York: LFB Scholarly Pub., 2003); Mary Nash \& Bruce Stewart, Spirituality and Social Care: Contributing to Personal and Community Well-Being (London: Jessica Kingsley Publishers, 2002); Procedural Justice and Group Dynamics \& Michael H. Tonry, A Review of Research (Chicago: University of Chicago Press, 2003); Tom R. Tyler \& American Bar Foundation, What is Procedural Justice?: Criteria Used by Citizens to Assess the Fairness of Legal Procedures (Chicago: American Bar Foundation, 1988): Tom R. Tyler \& Steven L. Blader. Cooperation in Groups: Procedural Justice. Socıal Identity: and Behavioral Engagememt (Philadelphia: Psychology Press, 2000).

Web of Science returns 208 records from social sciences and humanities journals containing the phrase "procedural justice" in the title. LegalTrac, an index of U.S. law journals, returns 70 articles (most of these will be theoretical or "black-letter," not empirical studies). The Index of Canadian Legal Literature does not return any articles.

3) This citation analysis was obtained through Web of Science. 22 September 2004. Web of Science indexes thousands of journals, 165 of them with "law" in their tilles, from 1945.

st For another example of a work by respected social sciences researchers, some with legal training, that was written for and neglected by a legal audience, see Kaplan, supra note 55 at 7 . The book was only reviewed once in a legal joumal, and has never been cited in a law journal, professional or academic. 
articles are of interest: 1978 saw the publication of Thibaut and Walker's main theoretical work in this area, "A Theory of Procedure," and in 1988, at what seems like a high point of the discussion on procedural justice, Monahan and Walker published "Social Science Research in Law: A New Paradigm," proposing a new research model for law topics."

First, Thibaut and Walker: unfortunately, though this major theoretical paper was published in the California Lav Review, not a single mainstream law journal figures in the top 10 citing journals. It was intended for a legal audience, but it was actually cited mainly in psychology and interdisciplinary journals. It was also cited by management journals in significant numbers (see Table 2).

Table 2: Top Ten Joumals Citing Thibaut and Walker (1978)

( 163 citations total)

\begin{tabular}{|l|c|c|}
\hline Journal Name & $\#$ of citations & $\%$ of citations \\
\hline JOURNAL OF PERSONALITY AND SOCLAL PSYCHOLOGY & 16 & $9.8 \%$ \\
\hline JOURNAL OF APPLIED SOCIAL PSYCHOLOGY & 9 & $5.5 \%$ \\
\hline JOURNAL OF EXPERIMENTAL SOCIAL PSYCHOLOGY & 6 & $3.7 \%$ \\
\hline LAW AND HUMAN BEHAVIOR & 5 & 3.1 \\
\hline AMERICAN PSYCHOLOGIST & 4 & $2.5 \%$ \\
\hline JOURNAL OF APPLJED PSYCHOLOGY & 4 & $2.5 \%$ \\
\hline JOURNAL OF MANAGEMENT & 4 & $2.5 \%$ \\
\hline LAW \& SOCIETY REVIEW & 4 & $2.5 \%$ \\
\hline ACADEMY OF MANAGEMENT JOURNAL & 3 & $1.8 \%$ \\
\hline BASIC AND APPLIED SOCIAL PSYCHOLOGY & 3 & $1.8 \%$ \\
\hline
\end{tabular}

The article garnered about 20 percent of its citations from "law" journals and 14.3 percent from mainstream law journals (see Table 3).

Table 3: Top Ten Kinds of Journals Citing Thibaul and Walker (1978)

\begin{tabular}{|l|c|c|c|}
\hline Journal Type & of citations & $\%$ of citations & $\begin{array}{c}\% \text { in } \\
\text { mainstream } \\
\text { law journals }\end{array}$ \\
\hline PSYCHOLOGY, SOCIAL & 57 & $35.0 \%$ & \\
\hline LAW & 33 & $20.2 \%$, & $14.3 \%$ \\
\hline MANAGEMENT & 26 & $16.0 \%$ & \\
\hline PSYCHOLOGY, MULTIDISCIPLINARY & 18 & $11.0 \%$ & \\
\hline BUSINESS & 17 & $10.4 \%$ & \\
\hline PSYCHOLOGY, APPLIED & 12 & $7.4 \%$ & \\
\hline
\end{tabular}
Monahan \& Laurens Walker, "Social Science Research in Law: A New Paradigm" (1988) American Psychologist 465. 


\begin{tabular}{|l|c|c|c|}
\hline Journal Type & $\#$ of cilations & $\%$ of citations & $\begin{array}{c}\% \text { in } \\
\text { mainstream } \\
\text { law journals }\end{array}$ \\
\hline SOCIAL SCIENCES, INTERDISCIPLINARY & 6 & $3.7 \%$ & \\
\hline SOCIOLOGY & 6 & $3.7 \%$ & \\
\hline PSYCHOLOGY & 4 & $2.5 \%$ & \\
\hline ECONOMICS & 3 & $1.8 \%$ & \\
\hline
\end{tabular}

Publishing a major theoretical article on the social psychology of procedural justice in a mainstream law journal did have an effect: $14.3 \%$ is the best result we have seen. But the contrasting example is less positive. Monahan and Walker, which proposes a new research approach to legal subjects, was published in a psychology journal. Of the 29 citations made to it, not one appeared in a mainstream academic law journal, unless Judicature is counted (see Tables 4 and 5).

Table 4: Journals Citing Monahan and Walker (1988)

(29 citations tolal)

\begin{tabular}{|l|c|c|}
\hline Journal Name & of citations & $\%$ of citations \\
\hline LAW AND HUMAN BEHAVIOR & 10 & $34.5 \%$ \\
\hline AMERICAN PSYCHOLOGIST & 5 & $17.2 \%$ \\
\hline PSYCHOLOGY PUBLIC POLICY AND LAW & 3 & $10.3 \%$ \\
\hline BEHAVIORAL SCIENCES \& THE LAW & 2 & $6.9 \%$ \\
\hline JOURNAL OF APPLIED SOCIAL PSYCHOLOGY & 2 & $6.9 \%$ \\
\hline AMERICAN JOURNAL OF DISEASES OF CHII.DREN & $\mathrm{I}$ & $3.4 \%$ \\
\hline CANADIAN PSYCHOLOGY.PSYCHOLOGIE CANADIFNNE & $\mathrm{I}$ & $3.4 \%$ \\
\hline JUDICATURE & $\mathrm{I}$ & $3.4 \%$ \\
\hline PEDIATRICS & $\mathrm{I}$ & $3.4 \%$ \\
\hline PSYCHOLOGICAL REPORTS & $\mathrm{I}$ & $3.4 \%$ \\
\hline
\end{tabular}

Table 5: Kinds of Journals Citing Monahan and Walker (1988)

\begin{tabular}{|l|c|c|c|}
\hline Journal Type & of citations & $\%$ of citations & $\begin{array}{c}\% \text { in mainstream } \\
\text { law journals }\end{array}$ \\
\hline LAW & 18 & $62.1 \%$ & $0 \%($ or $3.4 \%)$ \\
\hline PSYCHOLOGY, SOCIAL & 12 & $41.4 \%$ & \\
\hline PSYCHOLOGY, MULTIDISCIPLINARY & 10 & $34.5 \%$ & \\
\hline HEALTH POLICY \& SERVICES & 3 & $10.3 \%$ & \\
\hline PEDIATRICS & 2 & $6.9 \%$ & \\
\hline PSYCHOLOGY, APPLIED & 2 & $6.9 \%$ & \\
\hline
\end{tabular}

The implication is that most of those publishing in mainstream law journals do not follow the relevant literature outside their field. Clearly, social scientists have some distance to go before they will appear on the horizon of the traditional legal academic. 


\section{INTERDISCIPLINARY AND NON-TRADITIONAL LEGAL RESEARCHERS}

By 1988 a survey of empirical research in civil procedure alone justified a double issue of Law and Contemporary Problems, featuring an extensive annotated bibliography. ${ }^{61}$ It is interesting to contrast a selection of that bibliography's titles on delay with our two earlier selections:

- Reducing Case Delay and the Costs of Civil Litigation: The Kentucky Economical Litigation Project

Screening and Tracking Civil Cases: Managing Diverse Caseloads in the District of Columbia

Protracted Civil Trials: Views from the Bench and the Bar

Who Sets the Pace of Litigation?

Measuring the Pace of Litigation in Federal and State Trial Courts

Modeling Court Delay

Ruling Out Delay: The Impact of Ohio's Rules of Superintendence on the Administration of Justice

- Justice Delayed: The Pace of Litigation in Urban Trial Courts

- Time-Oriented Models and the Legal Process: Reducing Delay and Forecasting the Future

- Case Management and Court Management in United States Court Districts

- Production of Court Services: An Analysis of Sale Effects and Other Factors

- An Experiment in Justice without Delay

- The Accelerated Civil Jury Trial Program in the District Court for the Eastern District of Pennsylvania

- Court Congestion and Crash Programs: A Case Study

- Auditing the Auditor System: A Study of Auditor Referrals in Suffolk County, Massachusetts

- $\quad$ Split Trials and Time Saving: A Statistical Analysis

- Dispatch and Delay: A Field Study of Judicial Administration in Pennsylvania

- Congested Calendars - and Why

- A Study in Pendency in Texas Litigation

The presence of terms such as "evaluation," "modeling," "measuring," "statistical analysis" and "case study" highlight specific methodological approaches, while others, such as "tracking," "caseloads" and "case management," reflect an interest in court statistics. In addition, there is a number of place names that indicates an awareness of the importance of particular circumstances and locale to research results.

A useful look at the field through the lens of the Law and Society Association was published in 1990, ${ }^{2}$ and in 1997 a book, summing up the accomplishments of the "sociolegal" field in the United Kingdom, was published. ${ }^{63}$ The third edition of Treviño's survey 
of theoretical works in the sociology of law was published in $2003,{ }^{64}$ and in the same year a chapter in The Oxford Handbook of Legal Studies offered a bird's-eye view of developments, ${ }^{65}$ and there are other British surveys of the field. ${ }^{60}$ At this point a comprehensive review of the entire literature is probably impractical.

Much empirical work is produced in conjunction with a number of socio-legal and sociology of law research institutions and associations in the United States, the United Kingdom, Europe and further afield. Prominent groups with substantial civil justice research agendas are: Centre for Law and Society (Edinburgh University), The Centre for Socio-Legal Studies (Oxford), The Center for the Study of Law and Society (Berkeley), The Law and Society Association (U.S.), the Rand Institute for Civil Justice (Santa Monica), the Onati International Institute for the Sociology of Law (Spain), the Federal Judicial Center of the American Bar Foundation, the International Sociological Association's Research Committee on Sociology of Law, Réseau Européen Droit et Société, Vereinigung für Rechtssoziologie (Germany) and the Socio-Legal Research Centre (Griffith University, Australia). Some of these research institutions are closely connected with faculties of law, and their empirical research can focus on the areas of law that were identified above as "mainstream" (criminal, torts, etc.), but can also extend beyond areas of substantive law to look at civil justice system topics.

Three major areas of work have been the access to justice, the experiences of consumers of legal services and evaluation research. ${ }^{67}$ Empirical studies in these areas focus on legal institutions and processes. In civil matters, studies most often examine those aspects of the system that are less codified in rules, such as the pervasive "settlement culture" in civil systems. ${ }^{68}$ Connected with this focus is the fact that empirical research generally tends to give a novel prominence to the perceptions of the consumer of legal services, and to highlight the ways in which legal professionals misunderstand and under- or misrepresent them. ${ }^{69}$

In addition to these general comments, some more specific currents can be highlighted. Of particular note is the work describing how the dynamics of the United States legal system unbalances access to the courts, as well as the substantive content of decisions. This work

Trevino, supra note 29.

Baldwin \& Davis, supra note 42.

Roger Cotterrell, Law's Community: Legal Theory in Sociological Perspective (New York: Oxford University Press, 1995); William Twining. Blackstone 's Tower: The English Law School (London: Stevens/Sweet \& Maxwell, 1994); and Donald Harris \& Keith Hawkins, The Ifuman Face of Law: Essays in Honour of Donald Harris (New York: Oxford University Press. 1997).

For evaluations of the experiences of consumers of legal services, see William L.F. Felstinger, Richard L. Abel \& Austin Sarat. "The Emergence and Transformation of Disputes: Naming. Blaming. Claiming..." (1980-81) I5 Law \& Soc'y Rev. 631. For evaluative rescarch, sec the critical essay by Pawson and Tilley Realistic Evaluations (Thousand Oaks: Sage. 1997). This overview was taken from Baldwin \& Davis, supra note 42. For a critical review of the empirical lilerature on access to justice. with conclusions drawn. see: Barbara Yngvesson \& Patricia llennessey, "Small Claims. Complex Disputes: A Review of the Small Claims Literature" (1975) 9 Law \& Soc y Rev. 219. It covers the main 14 empirical studies, some of them extensive, of the functioning of small claims courts in the United States.

Baldwin \& Davis, ibid. at 886.

Baldwin \& Davis, ibid. at 887-88. 
follows in the wake of Marc Galanter's "Why the 'Haves' Come Out Ahead." Other areas of interest have been family law, ${ }^{71}$ antitrust, ${ }^{72}$ United States state supreme courts ${ }^{73}$ and consumer rights. ${ }^{74}$ Strong interest continues in criminal law, ${ }^{75}$ litigation $\operatorname{costs}^{76}$ and the legal profession. ${ }^{77}$ More recently, impact studies, ${ }^{78}$ studies of tort-related subjects in the United $\mathrm{Kingdom}^{79}$ and research on the politics of the judiciary, ${ }^{80}$ have been prominent.

In Canada, the state of legal scholarship (and education) was the subject of the 1983 Arthurs Report. ${ }^{81}$ Prepared by a group of prominent jurists and professors (law and political science), the Report demonstrated the impoverished state of Canadian legal scholarship and made recommendations for the "invigoration of Canadian legal scholarship" based on "the need to diversify the types of legal scholarship being conducted, to strengthen the research community... and to communicate the results ... to relevant professional audiences, as well as to the public." ${ }^{82}$ One of the first visible effects of the Report was the establishment of the Canadian Law and Society Association and jts journal, the Canadian Journal of Law and Society. Now in its 22nd year, the journal has been Canada's only consistent source of nondoctrinal legal research. Still, in spite of several calls for empirical work in the first issue, many of the articles are theoretical, and only one title in the whole run includes the word empirical. $^{83}$ The index (to 1997) contains no entries for empirical, statistical or

Marc Galanter, "Why the 'Haves' Come Out Ahead: Speculations on the Limits of Legal Change" (1974) 9 Law \& Soc'y Rev. 95. It is one of the all-time most-cited legal articles, see Herbert M. Kritzer \& Susan S. Silbey, eds., In Litigation: Do the "Haves" Still Come Out Ahead? (Stanford: Stanford University Press, 2003) at 4.

David L. Chambers, Making Fathers Pay: The Enforcement of Child Support (Chicago: University of Chicago Press, 1979) and Lenore J. Weitzman. The Divorce Revolution: The Unexpected Social and Economic Consequences for Women and Children in America (New York: Free Press, 1985).

Lawrence J. White, ed., Private Amitrust Liligation: New Evidence, New Learning (Cambridge, Mass.: MIT Press, 1988).

L. Rev. 773 .

George L. Priest, “A Theory of the Consumer Product Warranty” (1981) 90 Yale L.J. 1297.

Stanton Wheeler, Kenneth Mann \& Austin Surat, Sitting in Judgement: The Sentencing of White.Collar Criminals (New Haven: Yale University Press, 1988) and David C. Baldus, George Woodworth \& Charles A. Pulaskj Jr., "Monitoring and Evaluating Contemporary Death Sentencing Systems: Lessons from Georgia" (1985) 18 U.C. Davis L. Rev. 1375.

David M. Trubek et al., "The Costs of Ordinary Litigation" (1983) 3I UCLA L. Rev. 72.

John P. Heinz et al., "Diversity, Representation, and Leadership in an Urban Bar: A First Report on a Survey of the Chicago Bar" [1976] Am. B. Found. Res. J. 717.

7m Friedman, "The Law and Society Movement," supra note 9 at 772

7v Hazel G. Genn, Hard Bargaining (Oxford: Clarendon Press, 1987) and Donald N. Dewees, David Duff \& Michacl Trebilcock, Exploring the Domain of Accident Law: Taking the Facts Seriously (Oxford: Oxford University Press, 1996).

See J.A.G. Griffith, The Politics of the Judiciany, 4th ed. (London: Fontana Press, 1991); David Robertson, Judicial Discretion in the House of Lords (New York: Oxford University Press, 1998); Martin A. Levin, Urban Politics and the Criminal Courts (Chicago: University of Chicago Press, 1977); and Samuel Estreicher \& John Sexton, Redefining the Supreme Court's Role: A Theory of Managing the Federal Judicial Process (New Haven: Yale University Press, 1986).

Consultative Group on Research and Education in Law, Law and Learning: Report to the Social Sciences and Humanilies Research Councll of Canada (Otawa: Minister of Supply and Services, 1983) (Chair: Harry A. Arthurs) (Arthurs Report].

H. W. Arthurs, "Every Whichway: New Directions for Canadian Socio-Legal Research (1983) I C.J.L.S. I at 1.

David Johnson, "The Canadian Regulatory System and Corporatism: Empirical Findings and Analytical Implications" (1993) 8 C.J.L.S. 95. In fact, the article presents the results, but not the methodology or data, of Johnson's Regulation, Accountability, and Democracy: A Study of Select Ontario Regulatory 
methodological topics. While a review of the journal tums up a variety of articles with importance of the empirical study of law and civil justice topics in particular, the overall effect of the Arthurs Report on Canadian legal scholarship has been limited. In 2003 the Journal published a group of essays on the 20th anniversary of the Report, and they are clear: "the global picture emerging 20 years later seems not very different," 84 and "we have not been as successful as hoped in addressing the concerns raised by the Consultative Group." On the topic of methodology, "[c]ompared with other sectors of the academy, law professors [remain] methodologically limited in their range of research approaches, and doctrinal research far outflanked sophisticated qualitative and quantitative research techniques found in the social sciences."86 Still, there are some bright spots. Most visibly, two prominent multiyear projects for socio-legal research in Canada have been established: the Law and Society Programme of the Canadian Institute for Advanced Research (1986-1996) and the Law Commission of Canada, which is a multi-disciplinary federal law reform agency created in $1997 .^{87}$

The limited scope of socio-legal research in Canada has not gone unnoticed abroad, either. Recently, as part of a survey of the health of the field in the United Kingdom, input on the Canadian scene was solicited. The responses from several Canadian scholars are unequivocal: there is a lack of empirical research in Canada because, in sharp contrast to other social sciences, legal academics are not trained in methodological issues and perverse academic publishing expectations discourage long-term research. Further, almost all the research that is conducted focuses on criminal topics, to the detriment of civil justice research.

It is telling that a recent survey of Canadian law teachers did not ask whether any of them employed empirical methods in their research. ${ }^{88}$ And in a 2001 survey of Canadian social scientists, while justice issues ranked highly as an area of interest, the emphasis was very much on criminal, not civil, justice. ${ }^{89}$

On the specific and fundamental question of public perceptions of justice, the verdict is, again, clear: "given the limited range and scope of existing Canadian research, the

Agencies (doctoral dissertation, University of Toronto, 1990) [unpublished].

24 Ruth Murbach, "Editorial” (2003) 18 C.J.L.S. 1 at 1.

as Roderick A. Macdonald, "Still 'Law' and Still 'Leaming'?" (1993) 8 C.J.L.S. 5 at 21.

8. Constance Blackhouse, "Revisiting the Arthurs Report Twenty Years Later" (1993) 8 C.J.L.S. 33 at 37. quoting Theresa Shanahan, A Report on Legal Scholarship: Law professors ' research activities in Ontario's English-speaking common law schools (Vancouver: Centre for Policy Studies in Higher Education and Training. Faculty of Education, University of British Columbia, 2002).

n7 Macdonald, supra note 85 at 5.

4. Anna Paletta, Christopher Blain \& David Antonowicz, Research Report: Canadian Lanv School Faculty' Survey (Ottawa: The Canadian Council of Law Dean and Reseasrch Stalistics Division, Department of Justice Canada, 2000).

* Karin Stein \& Anna Paletta, Canadian Social Science Faculy Survey (Ottawa: Department of Justice Canada, 2002) at 8. No faculty expressed an interest in "civil law" (classed under Governance) or in "dispute resolution" (classed under Alternative Approaches to Justice). In fact, civil justice topics were not clearly identified in the survey (see ibid. at 50-53). 
conclusions that can be drawn about public perceptions [of justice] are both modest and tentative." 10

\section{RECENT DEVELOPMENTS}

In Canada and the United Kingdom, developments in sociological methodologies have been influential in recent work. These studies have taken multiple method approaches that seek to involve members of the research communities in generating constructive suggestions in order to address issues and bring about needed systemic change. " Of particular note are three studies by Hazel Genn in the United Kingdom, ${ }^{92}$ and the work of the Civil Justice System and the Public Project, led by the Canadian Forum on Civil Justice. ${ }^{93}$ As noted, the Canadian Centre for Justice Statistics has, since 1999, been initiating a plan to begin collecting basic data on Canadian civil cases.

As mentioned above, researchers in the United Kingdom have also undertaken a survey of the academics working in the field to help develop a response to a number of factors that threaten to reduce the number of studies even further. ${ }^{94}$ The positive aspect of this undertaking is that it reflects an increasing awareness that greater attention to empirical research in civil justice is much needed. In the coming months the Canadian Forum on Civil Justice will be working to identify ongoing and prospective Canadian civil justice research, with a view to developing a research community interested in working with the justice community to better understand and improve this fundamental democratic institution.

\section{CONCLUSION}

The empirical study of legal issues now has a substantial history and an impressive breadth of subject coverage. This article has also shown that, at least in some areas of civil justice topics, issues have been explored in depth. The corpus includes much important work that is either exclusively focused on civil justice matters, or that has direct relevance for civil justice systems. However, the neglect of this work by practicing academics and the failure of law schools to adapt their core curricula to include empirical approaches and methodologies is a barrier to future research. This attenuation is matched by an equally inadequate education of researchers in other disciplines about the prospects of specializing in legal subjects, and civil justice issues in particular. In addition, a continued emphasis on criminal matters has diverted funding away from empirical research about civil justice system

* Sandra Wain, "Public Perceptions of the Civil Justice System" in Rethinking Civil Justice: Research Studies for the Civil Justice Review, vol. 1 (Toronto: Ontario Law Reform Commission, 1996) 39 at 45 quoted in Stratton's reply to a U.K. study, infra note 94.

These approaches are broadly termed Action Research. For an overview of current issues in Action Research, see Peter Reason \& Hilary Bradbury, Handbook of Action Research: Participative Injury and Practice (Thousand Oakes: Sage, 2001).

Hazel G. Genn, Paths to Justice: What People Do and Think about Going to Law (Portland: Hart, 1999) and Hazel G. Genn \& Alan Paterson, Paths to Justice. Scolland: What People in Scotland Do and Think about Going to Law (Portland: Hart, 2001).

This is a five year national study undertaken by the Forum in partnership with members of the justice community and academics. For details about this collaborative research initiative, see CFCJ, "Research," online: CFCJ <wuw.cfcj-fcjc.org/research.htm>.

94 Inquiry on Empirical Research in Law, The Consultation Document (London: The Inquiry, 2004), online: University College London <www.ucl.ac.uk/laws/genn/empirical/consultation/index.shtml>. 
issues. Unless a renewed and sustained effort is made to support the empirical study of civil justice systems in Canada, our conceptions of our own legal system will remain distorted by ignorance, and we will continue to struggle to counter seemingly intractable problems such as delay. In short, we will remain saddled with a parochial understanding of our own justice system, and we will continue to be unclear on the question of how well our civil justice system furthers democratic society in Canada. 